\title{
Air Quality Changes in Shanghai, China, and the Surrounding Urban Agglomeration During the COVID-19 Lockdown
}

\author{
Mikalai Filonchyk $^{1,2}$ (D) $\cdot$ Michael Peterson ${ }^{3}$ \\ Accepted: 15 October 2020 / Published online: 23 October 2020 \\ (C) Springer Nature Switzerland AG 2020
}

\begin{abstract}
COVID-2019 (COronaVIrus Disease 2019), discovered at the end of December 2019, has spread around the world, becoming a pandemic. To prevent its spread, many governments implemented strict lockdown measures, including the closure of factories and limitations on travel. These measures led to a decrease in human activity, affecting air pollutant emissions. This study evaluates air quality during the partial lockdown of Shanghai, the largest city in China, and the broader Yangtze River Delta region. It was found that daily concentrations of $\mathrm{PM}_{2.5}, \mathrm{PM}_{10}, \mathrm{SO}_{2}, \mathrm{NO}_{2}$, and $\mathrm{CO}$ during the lockdown period were reduced by $9 \%, 77 \%, 31.3 \%, 60.4 \%$, and $3 \%$ respectively, compared to the same period in 2019. Even with decreasing concentrations of $\mathrm{PM}_{2.5}$ and $\mathrm{PM}_{10}$, the overall values are still more than four times higher for the lockdown period than the World Health Organization (WHO) recommends for safe concentrations $\left(10 \mu \mathrm{g} / \mathrm{m}^{3}\right.$ and $\left.20 \mu \mathrm{g} / \mathrm{m}^{3}\right)$. This indicates the existence of other background sources that continue to make a significant contribution to air pollution in the region even with severe reductions in human activity. This study may be used to guide environmental policy, as it demonstrates to what extent the control of pollution sources can improve air quality.
\end{abstract}

Keywords COVID-19 $\cdot$ Lockdown $\cdot$ Shanghai $\cdot$ Air quality

\section{Introduction}

On December 31, 2019, a large number of pneumonia cases with unknown etiology was registered in Wuhan, Hubei Province, China. On January 9, 2020, the Chinese Center for Disease Control and Prevention announced the new coronavirus. While the outbreak was initially centered in Wuhan, Shanghai, the largest city in the country, was one of the first to implement preventive measures against COVID-19. The Shanghai Municipal Government declared a public health state of emergency and decided that trade, catering, services,

Mikalai Filonchyk

filonchyk.mikalai@gmail.com

Michael Peterson

mpeterson@unomaha.edu

1 Faculty of Geomatics, Lanzhou Jiaotong University, Lanzhou 730070, China

2 Gansu Provincial Engineering Laboratory for National Geographic State Monitoring, Lanzhou 730070, China

3 Department of Geography/Geology, University of Nebraska Omaha, Omaha, NE 68182, USA culture, education, sports, and other similar industries should suspend their activities. Initially, the public bus and rail transport continued as before the partial lockdown. Shanghai authorities ordered the suspension of bus services to other cities beginning January 26.

Measures to slow the spread of the virus led to a decrease in movements and minimized industrial activity. There was a tremendous impact on citizens' daily lives, leading to lower economic growth. It also created unique conditions for evaluating the impact of anthropogenic activities on air pollution in the country's largest city.

Research has shown that air quality in China and other countries improved significantly with the implementation of lockdowns (Fattorini and Regoli 2020; Filonchyk et al. 2020; He et al. 2020; Muhammad et al. 2020; Safarian et al. 2020; Zhu et al. 2020). Energy consumption decreased significantly due to reductions in urban transport and industrial activity during these periods. In China, the average daily electricity production in February fell by about $40 \%$. The Ministry of Transport of the People's Republic of China reported that the number of passengers until February 10, which covers almost the entire holiday season, decreased by $82 \%$ compared to 2019. Emissions were reduced as a result of decreased use of oil and coal. 
Studies have shown that pollutant concentrations decreased in many cities in China. A study in 366 urban areas from January 1 to April 30 in mainland China showed that concentrations of $\mathrm{PM}_{2.5}, \mathrm{PM}_{10}, \mathrm{SO}_{2}, \mathrm{NO}_{2}$, and $\mathrm{CO}$ decreased by $14 \%, 15 \%, 12 \%, 16 \%$, and $12 \%$ respectively compared from the same periods of 2019 (Chen et al. 2020). Over East China, according to Filonchyk et al. (2020), there was a decrease in atmospheric concentrations of $\mathrm{NO}_{2}$ and $\mathrm{CO}$ during lockdown, with reductions of $30 \%$ and $20 \%$ respectively compared with the same period in 2019. A study conducted for three cities in Hubei Province in central China-Wuhan, Jingmen, and Enshi-showed that in February 2020, during lockdown, the average concentrations of $\mathrm{PM}_{2.5}, \mathrm{PM}_{10}, \mathrm{SO}_{2}, \mathrm{CO}$, and $\mathrm{NO}_{2}$ were $30.1 \%, 40.5 \%, 33.4 \%, 27.9 \%$, and $61.4 \%$ lower than in the same period of 2017-2019 (Xu et al. 2020).

The aim of this study is to evaluate changes in air quality as a result of the lockdown for the largest urban conurbation in China. In systematically assessing the dynamic environmental impact of the COVID-19 lockdown, this study examines the major pollutant emissions including $\mathrm{PM}_{2.5}, \mathrm{PM}_{10}, \mathrm{NO}_{2}, \mathrm{SO}_{2}$, and $\mathrm{CO}$ before, during, and after the partial lockdown.

Both $\mathrm{PM}_{2.5}$ and $\mathrm{PM}_{10}$ are particulate types of pollutants. While these particles reduce visibility and cause the air to appear hazy, $\mathrm{PM}_{2.5}$ is a particularly harmful for lungs because the particle size of only $2.5 \mu \mathrm{m}$ means that they are able to travel deeply into the respiratory tract. In contrast to particulate pollutants, nitrogen dioxide $\left(\mathrm{NO}_{2}\right)$, sulfur dioxide $\left(\mathrm{SO}_{2}\right)$, and carbon monoxide (CO) are mostly colorless gases. Highintensity exposure to these gases can lead to major injury to humans, including death. $\mathrm{NO}_{2}$ exposure affects both the respiratory tract and the human immune system. Sulfur dioxide $\left(\mathrm{SO}_{2}\right)$ contributes to a variety of respiratory problems.

All of these pollutants for Shanghai and the surrounding region are compared with the values obtained during the same periods of previous years (2017-2019). This study complements existing studies that assess the effect of lockdown, and partial lockdown, on air quality.

\section{Materials and methods}

The Yangtze River Delta region is the most populous region in China, with Shanghai being the largest city in the country. Shanghai, with a population of over 24 million people, has a population density of 3816 people per $\mathrm{km}^{2}$ (SBS 2017). It is located in the Yangtze River Delta, an important financial and cultural center of the country, with a GDP of 3.81 trillion RMB. Along with a major port of the East China Sea, it is an important transportation hub for railways and roads, and air traffic. The territory of the city extends for $120 \mathrm{~km}$ from north to south and $100 \mathrm{~km}$ from west to east. The total area is $6340.5 \mathrm{~km}^{2}$, of which urban development covers nearly half at $2648.6 \mathrm{~km}^{2}$.
Shanghai is characterized by a typical subtropical climate with some features of a monsoon. The summer season is hot and humid. The average July temperature is around $27-29^{\circ} \mathrm{C}$. The average temperature in January ranges from 3 to $4{ }^{\circ} \mathrm{C}$, although minus temperatures are also frequent. In February and March, air temperatures rise to $5-6^{\circ} \mathrm{C}$ and $9-10^{\circ} \mathrm{C}$, respectively. The average number of rainy days is 129 , and the average rainfall for the year does not exceed 1250-1300 mm. About half of the rain falls in the summer months but direct arid periods are not observed. In winter and autumn, north and north-west winds prevail, and in spring and summer they are from south and southeast.

The mass concentrations of particulate matter $\left(\mathrm{PM}_{2.5}\right.$ and $\left.\mathrm{PM}_{10}\right)$, sulfur dioxide $\left(\mathrm{SO}_{2}\right)$, nitrogen dioxide $\left(\mathrm{NO}_{2}\right)$, and carbon monoxide (CO) were provided by the China National Environmental Monitoring Center of Ministry of Ecology and Environment of the People's Republic of China (http:// 106.37.208.233:20035/). All data were obtained on the basis of hourly averaged data for each atmospheric pollutant. Installed automated monitoring systems for monitoring the concentration of pollutants in the atmosphere operate in accordance with China Environmental Protection Standards HJ 193-2013 (for $\mathrm{SO}_{2}, \mathrm{NO}_{2}, \mathrm{O}_{3}$, and $\mathrm{CO}$ ) and $\mathrm{HJ}$ 655-2013 (for $\mathrm{PM}_{2.5}$ and $\mathrm{PM}_{10}$ ) (MEP 2013a, b). The data were obtained from January 1 to March 31, 2017-2020.

\section{Results and discussion}

Under lockdown measures, people were asked to stay at home, meetings were suspended, and transportation, with the exception of special vehicles, was largely prohibited. Shanghai also faced additional restrictions compared to other cities as authorities tried to contain a local outbreak in China's largest city.

While a significant contributing factor to the decrease of emissions is a sharp reduction in domestic and international air traffic, accounting for about $15 \%$ of global emissions, the number of cars on the city streets fell sharply. In 2019, there were about 4.1 million personal vehicles in Shanghai. During lockdown, only emergency vehicles and food transport trucks continued to operate. Bus routes operated but on a reduced schedule. All of these factors led to a sudden reduction in emissions of $\mathrm{NO}_{2}$ and other pollutants such as $\mathrm{SO}_{2}, \mathrm{CO}$, and both types of PM (Fig. 1).

Coinciding with lockdown was the celebration of the Lunar New Year. Many activities stop for the entire week, including trade and construction. This has a certain effect on energy consumption, production, and emissions. In the weeks before and after the Lunar New Year, coal-fired power generation decreases by about $50 \%$, leading to lower coal consumption and associated pollution (Myllyvirta 2020). In 2020, due to the spread of COVID-19, China's government initially 
Fig. 1 Daily mean concentrations of air pollutants $\left(\mu \mathrm{g} / \mathrm{m}^{3}\right.$ for $\mathrm{PM}_{2.5}$, $\mathrm{PM}_{10}, \mathrm{NO}_{2}, \mathrm{SO}_{2}$, and $\mathrm{mg} / \mathrm{m}^{3}$ for $\mathrm{CO}$ ) in Shanghai from January 1 to March 31, 2020
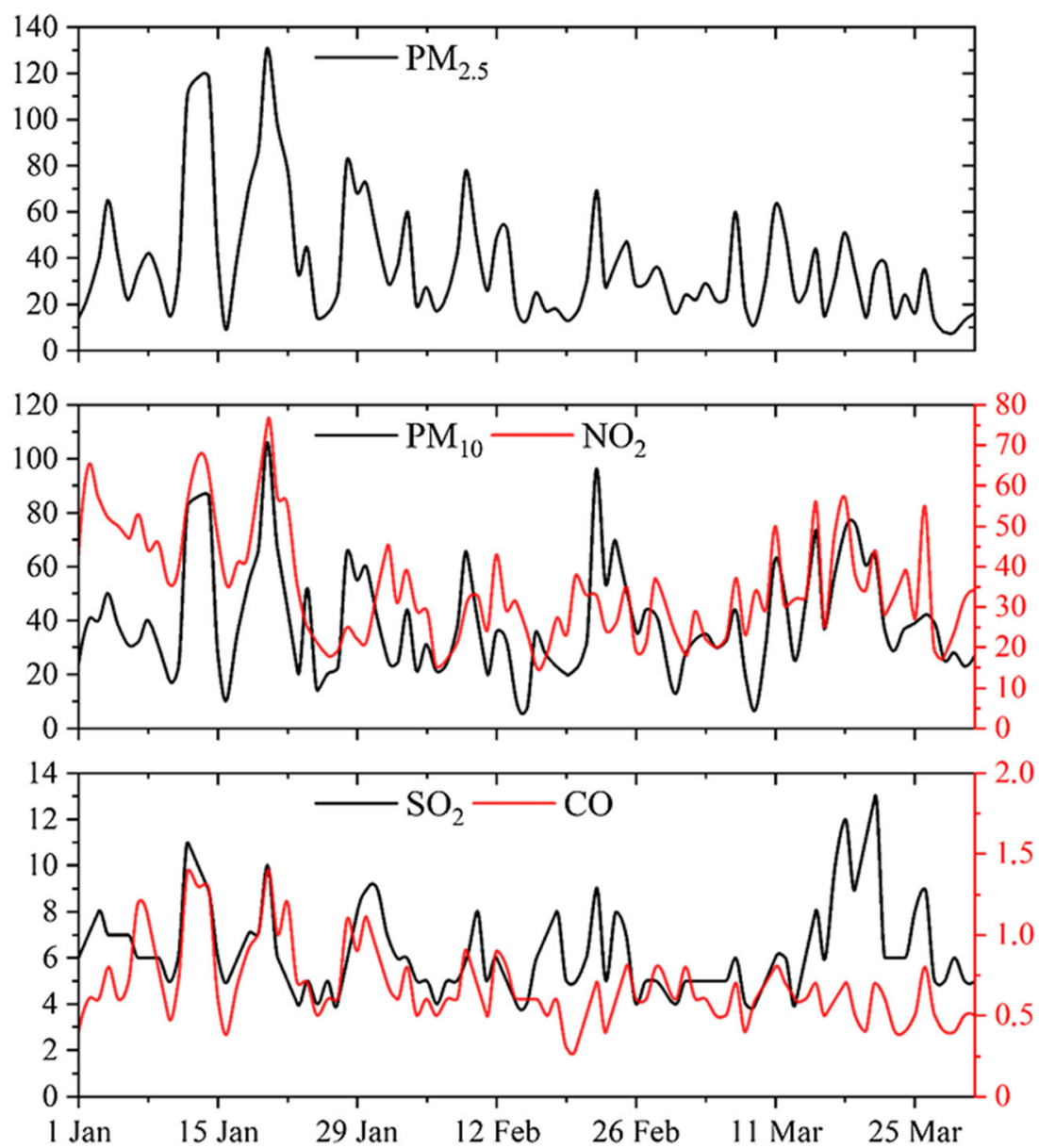

decided to extend the holidays in the country (until February 2 , in contrast to January 24 to 30 ) in order to reduce the possible crowding of a large number of people. The epidemiological situation was such that the Chinese authorities announced on January 31 a further extension of the vacation for another week, until February 9.

As can be seen from Fig. 1, starting from January 24, there was a sharp decrease in the concentration of pollutants, which could be associated both with the combination of the beginning of the Lunar New Year (January 24) and the lockdown measures taken against COVID-19. Even after February 10, when production officially resumed, air emissions were slow to recover to previous levels. As industrial production recovered, there was a gradual increase in fossil fuel consumption for the production of electricity. It is worth noting that particulate concentrations of $\mathrm{PM}_{2.5}$ and $\mathrm{PM}_{10}$ had similar values to the previous year. By the end of March, when lockdown was lifted, the concentration of pollutants in the atmosphere began to rise as many cars went on the road and enterprises resumed work. The country's largest Waigaoqiao Power Station (a coal-fired power station) in Pudong began operating at full capacity starting in mid-March, resulting in a sharp increase in $\mathrm{SO}_{2}$ concentrations.
For a more in-depth understanding of changes in pollutant concentrations, the data were classified and analyzed over a 2 week period. The concentrations of primary and secondary pollutants, determined from January 10 to March 6, 20172020, are shown in Fig. 2. The data were grouped so as to highlight the periods before, during, and after the lockdown. Four periods were allocated with a duration of 2 weeks: Period 1 (10 January-23 January), Period 2 (24 January-6 February), Period 3 ( 7 February-20 February) and Period 4 (21 February-6 March).

As shown in Fig. 2, the average concentrations of major air pollutants in Shanghai from January to March 2020 decreased compared to the same period in 2017-2019. In particular, in Period 1, the highest concentrations of pollutants were observed, later almost until the end of Period 4, when the implementation of epidemiological measures, the concentrations began to decrease. But as soon as anthropogenic activity began to resume, pollution levels reached their original levels (Fig. 1). However, based on the results from Table 1, a clear reduction in pollutant concentrations was tracked compared to identical periods in 2017 and 2018.

The main sources of $\mathrm{NO}_{2}$ are emissions from cars, ships, and the generation of electricity (Carslaw 2005; Kang et al. 2019; 

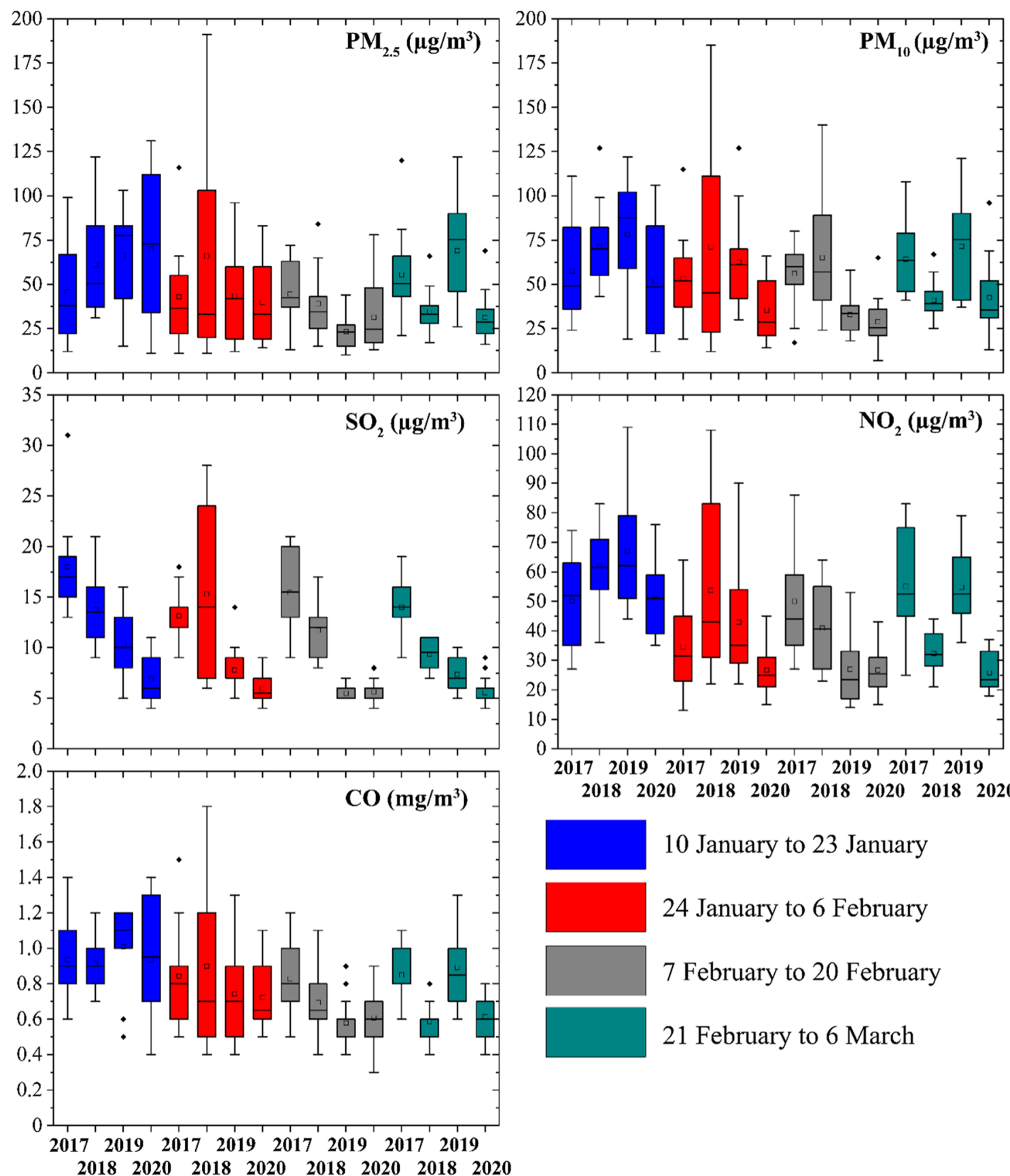

10 January to 23 January

24 January to 6 February

7 February to 20 February

21 February to 6 March

Fig. 2 Yearly changes of air pollutants in Shanghai during 10 January-6 March 2017-2020

Alshayef and Javed 2020; Chu et al. 2021; Filonchyk and Hurynovich 2020). An air pollutant is formed when a fossil fuel, such as coal, oil, gas or diesel, is burned at high temperatures. In addition to $\mathrm{NO}_{2}$, other pollutants are also formed. During lockdown, the number of vehicles on the roads decreased along with other human activities. This had a positive effect on air quality.

Data from the OMI (Ozone Monitoring Instrument) onboard the Aura satellite (Levelt et al. 2006). This instrument was intended for measuring the total content and profile of ozone, as well as for measuring key air quality components such as $\mathrm{NO}_{2}, \mathrm{SO}_{2}$, and aerosol (Boersma et al. 2007). By visualizing the OMI data (Fig. 3), a decrease in tropospheric $\mathrm{NO}_{2}$ concentration can be seen over the entire Yangtze River Delta, including Shanghai itself, and other large cities of the region (Hangzhou, Nanjing, Wuxi, Changzhou, Suzhou). Satellite data showed a similar pattern to measure surface concentrations of pollutants. In Fig. 3, the Shanghai area is highlighted with a black square. The time periods examined are 2 -week periods beginning January 10, followed by January 24, 2020 to March 6, 2020. 
Table 1 Mean concentration of $\mathrm{PM}_{2.5}, \mathrm{PM}_{10}, \mathrm{NO}_{2}, \mathrm{SO}_{2}$, and $\mathrm{CO}$ in Shanghai, China during 4 periods 2017-2020 (where A is ratio of $2020 \mathrm{vs} 2017$, B is ratio of 2020 vs 2018 , and $C$ is ratio of 2020 vs 2019)

\begin{tabular}{|c|c|c|c|c|c|c|c|}
\hline & \multicolumn{4}{|l|}{ Years } & \multicolumn{3}{|c|}{ Relative change (\%) } \\
\hline & 2017 & 2018 & 2019 & 2020 & A & $\mathrm{B}$ & $\mathrm{C}$ \\
\hline \multicolumn{8}{|c|}{ Period 1: 10 January-23 January } \\
\hline $\mathrm{PM}_{2.5}\left(\mu \mathrm{g} / \mathrm{m}^{3}\right)$ & 45.6 & 61.1 & 66.0 & 70.1 & +34.9 & +12.7 & +5.8 \\
\hline $\mathrm{PM}_{10}\left(\mu \mathrm{g} / \mathrm{m}^{3}\right)$ & 57.5 & 71.0 & 78.4 & 51.9 & -10.7 & -36.7 & -50.9 \\
\hline $\mathrm{SO}_{2}\left(\mu \mathrm{g} / \mathrm{m}^{3}\right)$ & 18.0 & 13.8 & 10.2 & 6.9 & -159.8 & -99.0 & -47.4 \\
\hline $\mathrm{NO}_{2}\left(\mu \mathrm{g} / \mathrm{m}^{3}\right)$ & 50.1 & 61.9 & 67.1 & 50.8 & +1.3 & -21.8 & -32.1 \\
\hline $\mathrm{CO}\left(\mathrm{mg} / \mathrm{m}^{3}\right)$ & 0.94 & 0.91 & 1.01 & 0.94 & 0.0 & +2.3 & -7.6 \\
\hline \multicolumn{8}{|c|}{ Period 2: 24 January-6 February } \\
\hline $\mathrm{PM}_{2.5}\left(\mu \mathrm{g} / \mathrm{m}^{3}\right)$ & 42.9 & 66.1 & 43.4 & 39.9 & -7.7 & -65.8 & -9.0 \\
\hline $\mathrm{PM}_{10}\left(\mu \mathrm{g} / \mathrm{m}^{3}\right)$ & 53.1 & 71.2 & 62.7 & 35.4 & -50.0 & -101.0 & -77.0 \\
\hline $\mathrm{SO}_{2}\left(\mu \mathrm{g} / \mathrm{m}^{3}\right)$ & 13.1 & 15.3 & 7.8 & 5.9 & -121.7 & -157.8 & -31.3 \\
\hline $\mathrm{NO}_{2}\left(\mu \mathrm{g} / \mathrm{m}^{3}\right)$ & 34.6 & 53.7 & 42.9 & 26.7 & -29.4 & -101.1 & -60.4 \\
\hline $\mathrm{CO}\left(\mathrm{mg} / \mathrm{m}^{3}\right)$ & 0.84 & 0.90 & 0.74 & 0.72 & -16.8 & -24.8 & -3.0 \\
\hline \multicolumn{8}{|c|}{ Period 3: 7 February-20 February } \\
\hline $\mathrm{PM}_{2.5}\left(\mu \mathrm{g} / \mathrm{m}^{3}\right)$ & 44.4 & 39.1 & 23.3 & 31.4 & -41.7 & -24.8 & +25.7 \\
\hline $\mathrm{PM}_{10}\left(\mu \mathrm{g} / \mathrm{m}^{3}\right)$ & 56.1 & 65.1 & 32.9 & 28.7 & -95.3 & -126.9 & -14.4 \\
\hline $\mathrm{SO}_{2}\left(\mu \mathrm{g} / \mathrm{m}^{3}\right)$ & 15.4 & 11.7 & 5.5 & 5.6 & -173.4 & -107.6 & +2.5 \\
\hline $\mathrm{NO}_{2}\left(\mu \mathrm{g} / \mathrm{m}^{3}\right)$ & 50.0 & 40.9 & 27.0 & 26.7 & -87.2 & -52.9 & -1.1 \\
\hline $\mathrm{CO}\left(\mathrm{mg} / \mathrm{m}^{3}\right)$ & 0.83 & 0.69 & 0.58 & 0.61 & -36.5 & -14.1 & +4.7 \\
\hline \multicolumn{8}{|c|}{ Period 4: 21 February-6 March } \\
\hline $\mathrm{PM}_{2.5}\left(\mu \mathrm{g} / \mathrm{m}^{3}\right)$ & 55.5 & 34.6 & 69.0 & 31.3 & -77.4 & -10.5 & -120.5 \\
\hline $\mathrm{PM}_{10}\left(\mu \mathrm{g} / \mathrm{m}^{3}\right)$ & 64.2 & 41.0 & 71.6 & 42.4 & -51.3 & +3.4 & -68.7 \\
\hline $\mathrm{SO}_{2}\left(\mu \mathrm{g} / \mathrm{m}^{3}\right)$ & 14.0 & 9.4 & 7.4 & 5.6 & -151.3 & -67.9 & -32.1 \\
\hline $\mathrm{NO}_{2}\left(\mu \mathrm{g} / \mathrm{m}^{3}\right)$ & 55.1 & 32.3 & 54.8 & 25.9 & -113.0 & -24.9 & -111.9 \\
\hline $\mathrm{CO}\left(\mathrm{mg} / \mathrm{m}^{3}\right)$ & 0.85 & 0.59 & 0.89 & 0.62 & -38.1 & +4.8 & -45.1 \\
\hline
\end{tabular}

In general, the lowest concentration of tropospheric $\mathrm{NO}_{2}$ was from late January to mid-February (Periods 2 and 3 ) than in other periods. Moreover, in comparison to the surrounding area, concentrations of tropospheric $\mathrm{NO}_{2}$ in Shanghai were higher than in other cities. This may indicate that it is difficult for a city of 24 million to control pollution, even during a lockdown. In Period 1 , before lockdown in Wuhan, tropospheric $\mathrm{NO}_{2}$ concentrations were high in Shanghai and the Yangtze River Delta. Industrial enterprises, power plants, traffic, and other anthropogenic activity were operating as normal.

Shanghai and the Yangtze River Delta is the most developed region of the country, with high population densities. Intensive industrial activity contributes to the release of large amounts of pollutants into the atmosphere (Wang et al. 2018). After Wuhan and other cities in the country began to lockdown from January 23 (Period 2), $\mathrm{NO}_{2}$ emissions decreased, improving air quality throughout the region. This seems a direct result of the closure of most enterprises and factories, and a reduction in the use of public and private transportation. The decrease in the concentration of pollutants in the atmosphere parallels the lockdown of cities.
After a reduction in the spread of COVID-19, the government announced that industrial enterprises would resume production from February 10 (Period 3). Many enterprises restarted their production facilities, leading to increased emissions. While the concentration of pollutants increased, they were still at lowered levels. The lockdown period made an important contribution to improving air quality in the region. But, this reduced amount of pollutants was temporary. At the end of February (Period 4), most enterprises returned to normal operation and the amount of $\mathrm{NO}_{2}$ emissions increased, leading to high tropospheric $\mathrm{NO}_{2}$ concentrations.

The results indicate that transport, industries, and commercial activities are the main sources of air pollution. After the economy returns to normal, future environmental standards will need to focus on the need to control emissions. Although there was an enhancement in air quality during this period, the level of air pollution after the closure of the city was still relatively high. Although many enterprises had suspended production during this lockdown period, $\mathrm{PM}_{2.5}$ and $\mathrm{PM}_{10}$ levels were still more than four times higher than those recommended by WHO as safe concentrations 

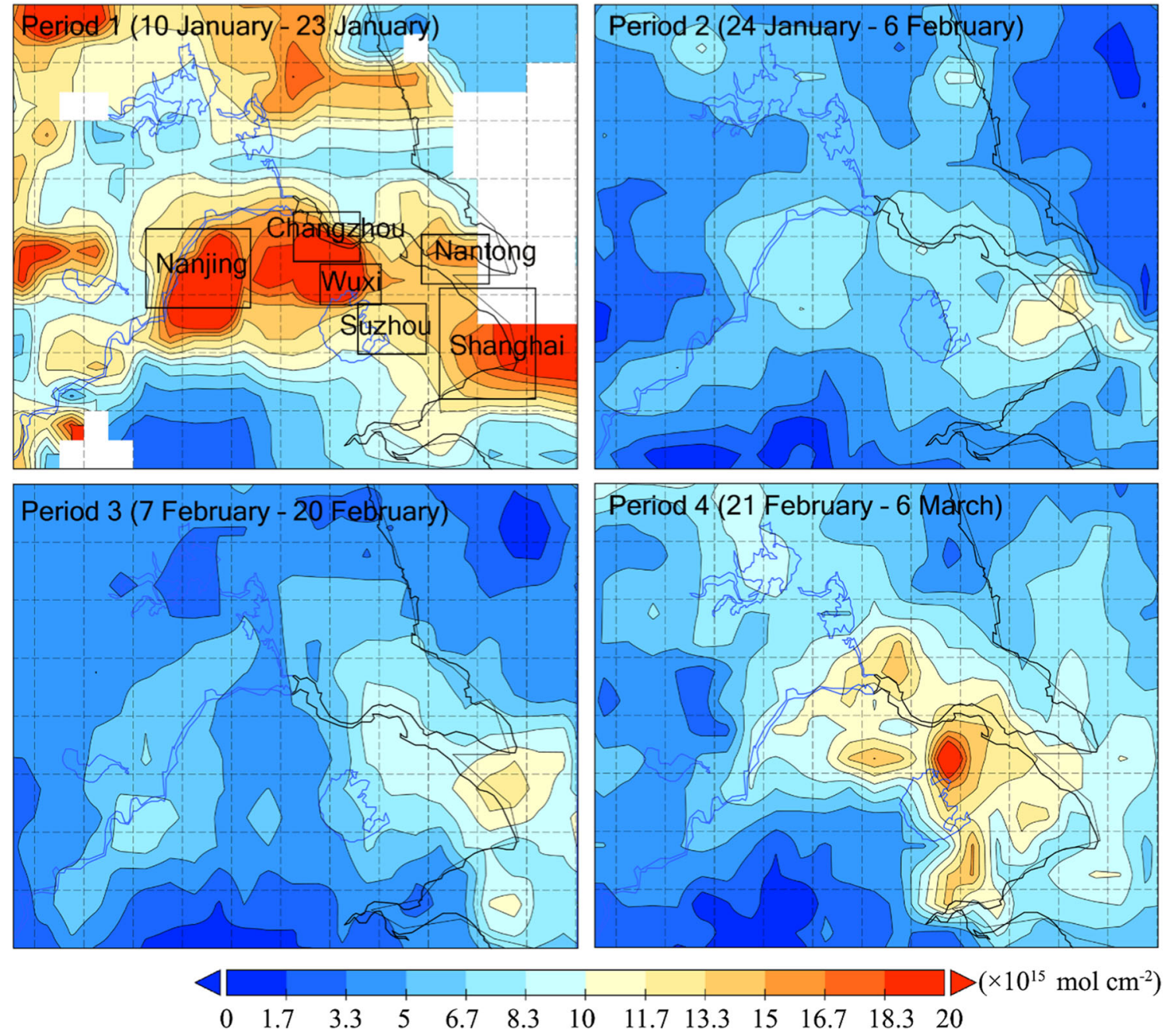

Fig. 3 Changes in tropospheric $\mathrm{NO}_{2}$ from OMI over Yangtze River Delta region

$\left(10 \mu \mathrm{g} / \mathrm{m}^{3}\right.$ and $20 \mu \mathrm{g} / \mathrm{m}^{3}$, respectively; WHO (2005)). This suggests that there were other sources of pollution that continued to make a significant contribution to air pollution. A contributing factor in air pollution monitoring are weather conditions that were not incorporated in this study. Nevertheless, with constant volumes and composition of emissions, fluctuations in the level of air pollution occur under the influence of the conditions of transport and dispersion of impurities, i.e., depend on the distribution of temperatures with height, wind speed and direction, the intensity of solar radiation and air humidity, the amount and duration of precipitation, and air temperature. Unfavorable meteorological conditions contributing to the accumulation of harmful pollutants in the surface layer of the atmosphere (calm, fog, dangerous wind direction, and speed) can increase the concentration of harmful ones (Liu et al. 2019; Wang et al. 2020). Therefore, for a more in-depth understanding of the impact of weather conditions on the concentration of pollutants in the future, it is necessary to conduct a full study.

\section{Conclusion}

This research has shown the degree to which lockdown affected air quality in Shanghai and the surrounding Yangtze River Delta in China. The main lockdown restrictions were introduced beginning January 24. By mid-February, lockdown restriction was weakened. Measures that limited economic activity, traffic and partial isolation of people before midFebruary led to a significant improvement in air quality. The concentrations of $\mathrm{PM}_{2.5}, \mathrm{PM}_{10}, \mathrm{SO}_{2}, \mathrm{NO}_{2}$, and $\mathrm{CO}$ during the lockdown period (January 24-February 6) were reduced by $9 \%, 77 \%, 31.3 \%, 60.4 \%$, and $3 \%$ respectively compared to the same the period in 2019. These reductions were shortterm. After a mid-February start-up, enterprises were fully operational by the end of February. Air quality began to deteriorate gradually throughout the latter part of February and into March, matching outputs from previous years. While lockdown led to many hardships, it demonstrated the role of human activity in contributing to air pollution. 
Funding This paper is supported by the National Key R\&D Program of China (2017YFB0504203), the China Postdoctoral Science Foundation Funded Project (2018M633605), and the Postdoctoral Fund of Lanzhou Jiaotong University (2018BH03001).

Compliance with Ethical Standards The authors of this paper will agree, accept, and comply with all the ethical standards set by the journal.

Conflict of Interest The authors declare that they have no conflict of interest.

Ethical Approval This paper does not contain any studies with human participants or animals performed by any of the authors.

Informed consent Informed consent was obtained from all individual participants included in the study.

\section{References}

Alshayef M S, Javed A (2020) Assessment of relative tectonics activity zones in Masila oil field, Yemen J Geovis Spat Anal 4(2), 1-17

Boersma KF, Eskes HJ, Veefkind JP, Brinksma EJ, van der Ronald AJ, Sneep M, van den Oord GHJ, Levelt PF, Stammes P, Gleason JF (2007) Near-real time retrieval of tropospheric NO2 from OMI. Atmos Chem Phys 7:2103-2118

Carslaw DC (2005) Evidence of an increasing NO2/NOx emissions ratio from road traffic emissions. Atmos Environ 39(26):4793-4802

Chen QX, Huang CL, Yuan Y, Tan HP (2020) Influence of COVID-19 event on air quality and their Association in Mainland China. Aerosol Air Qual Res 20:1541-1551

Chu B, Zhang S, Liu J, Ma Q, He H (2021) Significant concurrent decrease in PM2.5 and NO2 concentrations in China during COVID19 epidemic. J Environ Sci 99:346-353

Fattorini D, Regoli F (2020) Role of the chronic air pollution levels in the Covid-19 outbreak risk in Italy. Environ Pollut 264:114732

Filonchyk M, Hurynovich V (2020) Validation of MODIS aerosol products with AERONET measurements of different land covers types area over Eastern Europe and China. J Geovis Spat Anal 4:10

Filonchyk M, Hurynovich V, Yan H, Gusev A, Shpilevskaya N (2020) Impact assessment of COVID-19 on variations of SO2, NO2, CO and AOD over East China. Aerosol Air Qual Res 20:1530-1540

He G, Pan Y, Tanaka T (2020) The short-term impacts of COVID-19 lockdown on urban air pollution in China. Nat Sustain 1-7

Kang H, Zhu B, Zhu C, de Leeuw G, Hou X, Gao J (2019) Natural and anthropogenic contributions to long-term variations of $\mathrm{SO} 2, \mathrm{NO} 2$, CO, and AOD over East China. Atmos Res 215:284-293
Levelt PF, van den Oord GH, Dobber MR, Malkki A, Visser H, de Vries J, Saari H (2006) The ozone monitoring instrument. IEEE Trans Geosci Remote Sens 44(5):1093-1101

Liu N, Zhou S, Liu C, Guo J (2019) Synoptic circulation pattern and boundary layer structure associated with PM2.5 during wintertime haze pollution episodes in Shanghai. Atmos Res 228:186-195

MEP (Ministry of Environmental Protection of the People's Republic of China) (2013a) National standards on environmental protection: Technical specifications for installation and acceptance of ambient air quality continuous automated monitoring system for PM10 and PM2.5 (HJ655-2013). Ministry of Environmental Protection, China, Beijing

MEP (Ministry of Environmental Protection of the People's Republic of China) (2013b) National standards on environmental protection: Technical specifications for installation and acceptance of ambient air quality continuous automated monitoring system for $\mathrm{SO}$, $\mathrm{NO} 2$, O3 and CO (HJ193-2013). Ministry of Environmental Protection, China, Beijing

Muhammad S, Long X, Salman M (2020) COVID-19 pandemic and environmental pollution: A blessing in disguise? Sci Total Environ $728: 138820$

Myllyvirta L (2020) Analysis: coronavirus temporarily reduced China's $\mathrm{CO} 2$ emissions by a quarter. Carbon Brief https://www.carbonbrief. org/analysis-coronavirus-has-temporarily-reduced-chinas-co2emissions-by-a-quarter

Safarian S, Unnthorsson R, Richter C (2020) Effect of coronavirus disease 2019 on CO2 emission in the world. Aerosol Air Qual Res 20: $1197-1203$

SBS (Shanghai Bureau of Statistics) (2017) Shanghai statistical yearbook. China Statistics Press, Beijing (in Chinese)

Wang X, Guo Z, Wang Y, Chen Y, Zheng X, Xu X (2018) Monitoring temporal-spatial variations of AOD over the Yangtze River Delta. China Stoch Environ Res Risk Assess 32(9):2619-2632

Wang P, Chen K, Zhu S, Wang P, Zhang H (2020) Severe air pollution events not avoided by reduced anthropogenic activities during COVID-19 outbreak. Resour Conserv Recycl 158:104814

WHO (World Health Organization) (2005) World health organization air quality guidelines global update. In: Report on a Working Group Meeting, Bonn, Germany, 18-20 October 2005, WHO Regional Office for Europe E87950, report

Xu K, Cui K, Young LH, Hsieh YK, Wang YF, Zhang J, Wan S (2020) Impact of the COVID-19 event on air quality in Central China. Aerosol Air Qual Res 20(5):915-929

Zhu Y, Xie J, Huang F, Cao L (2020) The mediating effect of air quality on the association between human mobility and COVID-19 infection in China. Environ Res 189:109911

Publisher's Note Springer Nature remains neutral with regard to jurisdictional claims in published maps and institutional affiliations. 